\title{
Risk factors associated with intramammary colonization with Mollicutes in dairy cattle from Southeast Brazil
}

\author{
Ana Carolina Nunes de Morais ${ }^{1^{*}}$ (iD) Danielle Regis Pires ${ }^{1}$ (D) Nathalie Costa da Cunha ${ }^{1}$ (D) \\ Leandro dos Santos Machado ${ }^{1}$ (D) Michel Abdalla Helayel ${ }^{1}$ (iD \\ Juliana França Monteiro de Mendonça ${ }^{1}$ (D) Guilherme Nunes de Souza ${ }^{1,2}$ (D) \\ Maria Lucia Barreto ${ }^{1}$ (D) Elmiro Rosendo do Nascimento ${ }^{1}$ (i)
}

1Departamento de Saúde Coletiva Veterinária e Saúde Pública (MSV), Faculdade de Veterinária, Universidade Federal Fluminense (UFF), 24230-340, Niterói, RJ, Brasil. E-mail: acnmorais@id.uff.br. "Corresponding author.

${ }^{2}$ Empresa Brasileira de Pesquisa Agropecuária (EMBRAPA), Gado de Leite, Juiz de Fora, MG, Brasil.

ABSTRACT: Bacteria of Mollicutes Class are associated with intramammary infection and decrease in milk production. This study investigated the occurrence of Mollicutes and elucidated their risk factors in dairy herds from Southeast Brazil. For this, milk samples from 387 lactation cows from Minas Gerais, Rio de Janeiro and São Paulo States were subjected to the polymerase chain reaction (PCR) to detect Mollicutes. Species of Mycoplasma were investigated in Mollicutes positive samples by PCR, including Mycoplasma bovis, M. alkalescens, M. bovigenitalium, M. bovirhinis, M. arginini and A. laidlawii. An epidemiological questionnaire was applied to collect data on possible risk factors, which were assessed using Pearson's Chi-square test followed by odds ratio ( $P \leq 0.05)$. Mollicutes were reported in 21\% (4/19) of the herds and 4\% (16/387) of the animals, while 1\% (5/387) were positive for M. bovis and 3\% (11/387) for M. arginini. All samples were negative to the other agents. Herds with more than 150 animals [OR=3.51 (95\% CI 1.11-11.08)], manual milking [OR=9.97 (95\% CI 2.8035.49)] and not-milking animals with mastitis last [OR=6.54 (95\% CI 1.92-22.29)] were risk factors. The presence of these conditions may favor intramammary infection by Mollicutes in dairy herds from Southeast Brazil. This is the first report of M. bovis in Rio de Janeiro and M. arginini in the studied states.

Key words: bovine milk, Mycoplasma bovis, Mycoplasma arginini, herd size, milking.

Fatores de risco associados à colonização intramamária por Mollicutes em bovinos leiteiros do Sudeste brasileiro

RESUMO: Bactérias da Classe Mollicutes estão associadas à infecção intramamária e diminuição da produção leiteira. O objetivo deste estudo foi investigar a ocorrência de Mollicutes e elucidar seus fatores de risco em rebanhos leiteiros do sudeste brasileiro. Para isso, amostras de leite de 387 vacas em lactação dos estados de Minas Gerais, Rio de Janeiro e São Paulo foram submetidas à reação em cadeia da polimerase (PCR) para detectar Mollicutes. Espécies de Mycoplasma foram investigadas nas amostras positivas por PCR, incluindo Mycoplasma bovis, M. alkalescens, M. bovigenitalium, M. bovirhinis, M. arginini e A. laidlawii. Foi aplicado um questionário epidemiológico para a coleta de dados sobre possiveis fatores de risco, que foram avaliados pelo teste de Qui-Quadrado de Pearson seguido de odds ratio $(P \leq 0.05)$. Mollicutes foram detectados em $21 \%$ (4/19) dos rebanhos e 4\% (16/387) dos animais, enquanto 1\% (5/387) destes foram positivos para m. bovis, 3\% (11/387) para m. arginini, sendo todas as amostras negativas para os demais agentes. Rebanhos com mais de 150 animais [OR=3,51 (95\% IC 1,11-11,08)], ordenha manual [OR=9,97 (95\% IC 2,80-35,49)] e ausência de linha de ordenha [OR=6,54 (95\% IC 1,9222,29)] foram considerados fatores de risco. A presença dessas condições pode favorecer a infecção intramamária por Mollicutes em rebanhos leiteiros no sudeste do Brasil. Este é o primeiro relato de M. bovis no Rio de Janeiro e M. arginini nos estados estudados.

Palavras-chave: leite bovino, Mycoplasma bovis, Mycoplasma arginini, tamanho do rebanho, ordenha.

\section{INTRODUCTION}

Bovine milk production is of great importance for agribusiness in Brazil (TELLES et al., 2020). Dairy farming is practiced all over the country, being essential for providing food, jobs and income to population. In 2017, Brazil produced 33.5 billion liters of milk, and the Southeast region, was responsible for around $34 \%$ of production, being Minas Gerais considered the greater brazilian dairy basin (EMBRAPA, 2019).

Despite the large milk production, poor quality of raw milk due to microbiological contamination is one of the biggest obstacles to 
the consolidation of dairy industry in Brazil, since contamination interferes on the quality of pasteurized milk or used on derivatives manufacturing (LANGE et al., 2017). Bacteria from Mollicutes Class, which are the smallest self-replicating organisms known, are related to intramammary infection in dairy cattle. Although, different species of Mollicutes were already isolated from bovine milk including Mycoplasma bovis, M. arginini, M. alkalescens, $M$. canadense, M. bovirhinis, M. bovigenitalium, $M$. californicum, M. dispar, Acholeplasma laidlawii, A. oculi and A. granularum, M. bovis is considered the most prevalent and clinically important species, being the most extensively studied bovine mycoplasma (GONZÁLEZ \& WILSON, 2003; GIOIA et al., 2016). Besides intramammary infection, M. bovis is associated with arthritis, otitis, bronchopneumonia, conjunctivitis, genital disorders, and meningitis, since it can colonize the mucosal surface of a wide variety of tissues (BÜRKI et al., 2015).

In Brazil, research on this agent and other mycoplasmas in herds is still neglected and no research is referred to the etiology of Mycoplasma spp. infection in the mammary glands. Thus, it is difficult to compare the occurrence of the most prevalent species of these agents in the country (SALINA et al., 2020). The first isolation of $M$. bovis from bovine milk occurred in a mastitis outbreak in Paraná (METTIFOGO et al., 1996) and, since then, few studies have been conducted, restricting the identification of the agent in herds in Paraná, São Paulo, Minas Gerais and Goiás, with occurence in animals ranging from 1 to $3 \%$ (PRETTO et al., 2001; FRANCHESCHINI et al., 2008; JUNQUEIRA, 2017; JOAQUIM et al., 2018; MANZI et al., 2018).

Herd size is being suggested a risk factor for intramammary infection by mycoplasmas. In farms where there is acquisition of animals for breeding stock replenishment, there is a greater risk for the introduction of Mycoplasma spp. when compared to closed herds, due to high cow turnover rate and the greater probability of acquiring an infected animal (AL-MOMANI et al., 2008; PINHO et al., 2013). The exposure of naive cattle to Mollicutes as a result of entrance of symptomatic or asymptomatic animals may explain the greater presence of mycoplasmal mastitis in countries with more cattle movement (FOX, 2012; MATOS et al., 2019). In this sense, purchased cattle may be one of the major pathways of the agent incursion, which is associated to failures in biosafety, such as poor stringent separation or quarantine protocols (MURAI \& HIGUCHI, 2019).

Also, corporation-type farms are a risk factor to intramammary infection by Mollicutes, due to the frequency of moving cows and fomites compared to family-run farms (MURAI \& HIGUCHI, 2019). Besides, management practices, mostly those related to milking, such as well-functioning milking machines, proper milking procedures and sanitation are of great importance to prevent the infection, as well as the proper cleaning and disinfection of milking utensils. In larger herds, udder preparation may be neglected in favor of moving cows rapidly through the milking parlor and milkers trained to emphasize speed of milking do not usually practice thorough teat dipping. Other factors have not yet been clearly associated with the presence of Mycoplasma spp. in herds (GONZÁLEZ \& WILSON, 2003; ALMOMANI et al., 2008; PINHO et al., 2013).

The current lack of information about Mollicutes circulation in Brazilian herds provided the motivation for this study, which investigated the occurrence of Mollicutes and elucidated their risk factors in dairy herds.

\section{MATERIALS AND METHODS}

Sampling to obtain the minimum number of animals was based on the formula $n=Z^{2} \times P$ (1P)/E ${ }^{2}$, described by THURSFIELD (2003), where $\mathrm{Z}$ refers to the confidence interval, $\mathrm{P}$ the estimated prevalence and $\mathrm{E}$ the error. In the current study, $\mathrm{Z}$ value was $95 \%$, P value $50 \%$ (since the prevalence of the intramammary infection by Mollicutes in the region is unknown) and $\mathrm{E}$ value $5 \%$, obtaining a minimum sample of 384 animals to be analyzed.

Based in a cross-sectional study, between March 2018 and July 2019, samples of 387 animals were obtained from dairy cattle herds in the states of Minas Gerais $(n=148)$, Rio de Janeiro $(n=136)$ and São Paulo ( $\mathrm{n}=103)$, totaling 19 herds.

The selection of herds was made by convenience (non-probabilistic sampling), highlighting that only herds with a previous history of recent clinical mastitis were selected for this study. Besides, in each herd, animals without any clinical signs of mastitis and already included in the milking parlor were randomly selected.

Milk was collected from animals of several ages, breeds and lactation stages during morning or afternoon milking, preceded by hygiene and antisepsis of the teats. Samples were composed by mixing equal parts of milk from each teat and placed in sterile bottles with a screw cap, transported under refrigeration $\left(4^{\circ} \mathrm{C}\right)$, and subsequently, kept at $-20{ }^{\circ} \mathrm{C}$ until laboratory analyses were carried out. Concomitantly with the material collection, an 
epidemiological questionnaire was applied with closed questions to investigate milking management practices and data on zootechnical characteristics of the herds.

Milk samples were initially centrifugated by $1331 \mathrm{x} \mathrm{g}\left(\mathrm{HT}^{\circledR}\right)$ for 15 minutes and the upper fatty layer was removed using a sterile pipette, and the supernatant was discarded, as a pre-treatment step in order to minimize the PCR inhibitors in milk. Then, the remaining material was used to DNA extraction, performed from $100 \mu \mathrm{L}$ of each sample, using the commercial kit DNeasy ${ }^{\circledR}$ Blood and Tissue kit (Qiagen ${ }^{\mathrm{TM}}$ ), according to the methodology proposed by the manufacturer. The extracted DNA was evaluated in a Biodrop ${ }^{\mathrm{TM}} \mathrm{UV} / \mathrm{VIS}$ spectrophotometer, in terms of concentration $(\mathrm{ng} / \mu \mathrm{L})$ and purity degree, so that in each reaction a standard concentration of DNA template $(100 \mathrm{ng} / \mu \mathrm{L})$ was added.

Initially, a screening was carried out, using PCR to detect Mollicutes, with a total reaction volume of $25 \mu \mathrm{L}$, containing a reaction buffer $(10 \mathrm{mM}$ Tris $\mathrm{HCl} \mathrm{pH} 8.0$ ) 1x, $2.0 \mathrm{mM} \mathrm{MgCl}_{2}, 0.2 \mathrm{mM}$ dNTP, 0.2 $\mu \mathrm{M}$ primers and 1.0 U Taq Polymerase (LudwigTM). Positive samples in this assay were submitted to PCR to identify Mollicutes species, M. bovis, M. arginini, M. alkalescens, M. bovigenitalium, M. bovirhinis and $A$. laidlawii, which have already been isolated from bovine milk and implicated in intramammary infection in dairy cattle.

For the detection of $M$. bovis the reaction was performed in a volume of $25 \mu \mathrm{L}$, containing reaction buffer (10 mM Tris $\mathrm{HCl} \mathrm{pH} 8.0) 1 \mathrm{x}, 1.5$ $\mathrm{mM} \mathrm{MgCl}, 0.2 \mathrm{mM} \mathrm{dNTP}, 0.2 \mu \mathrm{M}$ primers, $1.0 \mathrm{U}$ of Taq Polymerase (LudwigTM). For M. arginini, $M$. alkalescens, $M$. bovigenitalium and $M$. bovirhinis, the reaction was equivalent to the previous one, except for the concentration of $1.0 \mathrm{mM}$ dNTP and $0.4 \mu \mathrm{M}$ primers. For A. laidlawii, the reaction likewise differed in the concentration, $0.2 \mathrm{mM}$ dNTP and $0.8 \mu \mathrm{M}$ primers. The primers and the references for thermal profiles for each reaction are described in table 1.

DNA extracted from isolates of each Mycoplasma species and Acholeplasma laidlawii were obtained from field samples and used as a positive control for all reactions and nuclease-free water was used as a negative control.

The amplified products were submitted to the electrophoretic run at $90 \mathrm{mV}$, on a $1.5 \%$ agarose

Table 1 - Description of primers and references for thermal profiles in generic pcr for mollicutes and specific pcr for mycoplasma species and Acholeplasma laidlawii.

\begin{tabular}{|c|c|c|c|c|c|}
\hline $\begin{array}{l}\text { Primer } \\
\text { designation }\end{array}$ & Sequencing $5^{\prime} 3^{\prime}$ & Species & Targets & $\begin{array}{l}\text { Amplicon } \\
\text { size (bp) }\end{array}$ & $\begin{array}{l}\text { Reference for } \\
\text { thermal profile }\end{array}$ \\
\hline $\begin{array}{l}\text { GPO3 } \\
\text { MGSO }\end{array}$ & $\begin{array}{c}\text { GGG AGC AAA CAG GAT TAG } \\
\text { ATA CCC T } \\
\text { TGC ACC ATC TGT CAC TCT } \\
\text { GTT AAC CTC }\end{array}$ & Mollicutes & 16S rRNA & 270 & $\begin{array}{l}\text { VAN } \\
\text { KUPPEVELD et al. } \\
(1992)\end{array}$ \\
\hline Mbo R & $\begin{array}{c}\text { CCT TTT AGA TTG GGA TAG } \\
\text { CGG ATG } \\
\text { CCG TCA AGG TAG CAT CAT } \\
\text { TTC CTA T }\end{array}$ & M. bovis & 16S rRNA & 360 & $\begin{array}{l}\text { CHÁVEZ- } \\
\text { GONZALEZ et al. } \\
\text { (1995) }\end{array}$ \\
\hline $\begin{array}{l}\text { Myc } 1 \mathrm{~F} \\
\text { M. arginini }\end{array}$ & $\begin{array}{c}\text { CAC CGC CCG TCA CAC CA } \\
\text { GTT GTA TGA CCT ATT GTT GTC }\end{array}$ & M. arginini & $\begin{array}{l}16 \mathrm{~S} / 23 \mathrm{~S} \\
\text { rRNA }\end{array}$ & 312 & $\begin{array}{l}\text { CHALKER et al. } \\
\qquad(2004)\end{array}$ \\
\hline $\begin{array}{l}\text { Mak F } \\
\text { Mak R }\end{array}$ & $\begin{array}{c}\text { CCG TCA AGG TAG CAT CAT } \\
\text { TTC CTA T } \\
\text { AGA GTC CTC GAC ATG ACT CG }\end{array}$ & M. alkalescens & 16S rRNA & 704 & $\begin{array}{l}\text { KOBAYASHI et al. } \\
\text { (1998) }\end{array}$ \\
\hline $\begin{array}{l}\mathrm{MbgF} \\
\mathrm{MbgR}\end{array}$ & $\begin{array}{c}\text { CGT AGA TGC CGC ATG GCA } \\
\text { TTT ACG G } \\
\text { CAT TCA ATA TAG TGG CAT } \\
\text { TTC CTA C }\end{array}$ & $\begin{array}{c}\text { M. } \\
\text { bovigenitalium }\end{array}$ & 16S rRNA & 312 & $\begin{array}{l}\text { KOBAYASHI et al. } \\
\text { (1998) }\end{array}$ \\
\hline $\begin{array}{l}\mathrm{M} b r \mathrm{~F} \\
\mathrm{M} b r \mathrm{R}\end{array}$ & $\begin{array}{l}\text { GCT GAT AGA GAG GTC TAT CG } \\
\text { ATT ACT CGG GCA GTC TCC }\end{array}$ & M. bovirhinis & 16S rRNA & 316 & $\begin{array}{l}\text { KOBAYASHI et al. } \\
\text { (1998) }\end{array}$ \\
\hline $\begin{array}{l}\mathrm{ACH} 3 \\
\mathrm{UNI}\end{array}$ & $\begin{array}{l}\text { AGC CGG ACT GAG AGG TCT AC } \\
\text { TAA TCC TGT TTG CTC CCC AC }\end{array}$ & A. laidlawii & 16S rRNA & 505 & $\begin{array}{l}\text { DUSSURGET \& } \\
\text { ROULLAND- } \\
\text { DUSSOIX (1994) }\end{array}$ \\
\hline
\end{tabular}


gel, added with $0.025 \mu \mathrm{L} / \mathrm{mL}$ of ethidium bromide, with a $100 \mathrm{bp}$ molecular marker. The gel was visualized in a UV light transluminator and the image captured for photodocumentation.

Data were compiled in Microsoft Excel ${ }^{\circledR}$ spreadsheets and checked for possible inconsistencies, resulting in 12 explanatory variables associated to herd structure and husbandry practices that could be potential risk factors based on previous studies (GONZÁLEZ \& WILSON, 2003; FOX, 2012; PINHO et al., 2013; MURAI \& HIGUCHI, 2019), as follows: herd size, average herd production, breeding system, predominant age group, predominant breed, quarantine, milking type, washing and drying teats with individual paper towel, premilking and postmilking teat disinfection, milking animals with mastitis last, cleaning and disinfecting the stables and surroundings. Pearson's Chi-square test was performed and variables with statistical significance less than 0.10 (MURAI \& HIGUCHI, 2019), were submitted to univariate analysis, by odds ratio $(95 \%$ CI) to analyze the potential risk factors associated with Mollicutes intramammary colonization. All statistical analyses were performed in BioStat $^{\mathbb{B}}$ software (AYRES et al., 2007).

\section{RESULTS AND DISCUSSION}

The frequency of infection was $21 \%(4 / 19)$ for Mollicutes in dairy herds. Regarding the withinherd frequency, 4\% (16/387) of milk samples were positive for Mollicutes. In Brazil, no research is referred to the etiology of Mycoplasma spp. infection in the mammary glands and it is difficult to compare the occurrence of the most prevalent species of this agent in the country (SALINA et al., 2020).

Risk factors associated with intramammary infection by Mollicutes were herds with more than 150 animals $[\mathrm{OR}=3.51$ (95\% CI 1.11-11.08)], manual milking $[\mathrm{OR}=9.97$ (95\% CI 2.80-35.49)] and notmilking animals with mastitis last $[\mathrm{OR}=6.54(95 \%$ CI 1.92-22.29)] $(\mathrm{P}<0.05)$ (Table 2). According to PINHO et al. (2013) herd size is the major risk factor to mycoplasmal intramammary infection. In the current study, the greatest risk of detecting Mollicutes was reported in herds with more than 150 animals, possibly because expanding herds is associated with greater circulation of animals (buying and selling), possible failures in the biosafety practices and a greater possibility of introducing the agent, usually from asymptomatic individuals.

Mycoplasma spp. have been considered contagious in nature, being transmitted mostly at milking from an infected udder to an uninfected cow or from an infected mammary quarter to another one. Possibly, in the studied herds, manual milking was associated with failures in the care of the milker, at the time of milking, since mycoplasmas can be transmitted from fomites and milker's hands, which highlights that the qualification and involvement of milkers is essencial to prevent infection (GONZÁLEZ \& WILSON, 2003; FOX, 2012; LANGE et al., 2017). Besides, when there is no separation between healthy and mastitic animals during milking, animals with different sanitary status are milked randomly and new cases of intramammary infection increase, since mycoplasmas can be disseminated by fomites, milk, nose to nose contact or aerosols (FOX, 2012; WAWEGAMA et al., 2016).

From positive samples in screening, $31 \%$ (5/16) were positive for $M$. bovis, $69 \%(11 / 16)$ for $M$. arginini, and there was co-infection in $19 \%(3 / 16)$. The description of positive samples for Mollicutes in specific PCR is shown in table 3. No positive samples were reported for the species $M$. alkalescens, $M$. bovigenitalium, M. bovirhinis and A. laidlawii.

The frequency of $M$. bovis infection was compatible with previous research carried out in Brazil by PRETTO et al. (2001), JUNQUEIRA (2017), MANZI et al. (2018) and SALINA et al. (2020) who detected an occurence ranging from 1 to $3 \%$. In Australia, low frequencies for $M$. bovis infection were reported by MORTON et al. (2014), who stated that; although, the microorganism is present in less than $1.0 \%$ of herds, it can cause severe disease in some of them. LYSNYANSKY et al. (2015) reported an increase in the prevalence of $M$. bovis mastitis in Israeli herds, going from 0 to $0.68 \%$ in the period from 2004 to 2007 to $3.77 \%$ during an outbreak in 2008 , reaching a frequency of 0.77 to $2.77 \%$ between 2009 and 2014. Thus, despite the low frequency reported in the current study, diagnosis is essencial to know the occurrence of the agent in brazilian herds. Besides, it is necessary to adopt infection control actions, whereas $M$. bovis usually causes subclinical or mild clinical intramammary infection, which can progress to chronic mastitis or severe clinical mastitis outbreaks, impacting on animal health and economy, since culling is the most adequate measure for the infection control (NICHOLAS et al., 2016; TIMONEN et al., 2017).

Mycoplasma bovis is the most extensively studied and understood bovine mycoplasma worldwide; however, other species can be detected alone or in co-infection with $M$. bovis in bovine milk (GIOIA et al., 2016), such as M. arginini, which was 
Table 2 - Risk analysis for intramammary colonization by Mollicutes in dairy cattle herds from Southeast Brazil.

\begin{tabular}{|c|c|c|c|c|c|c|}
\hline Variable & Category & $\mathrm{N}$ & $\begin{array}{c}\text { PCR Mollicutes } \\
(\%)\end{array}$ & $\begin{array}{c}\mathrm{P}- \\
\text { value }^{1}\end{array}$ & Odds ratio $(95 \% \mathrm{CI})$ & P- value ${ }^{2}$ \\
\hline \multirow{2}{*}{ Herd size } & Until 150 & 204 & $4(2)$ & \multirow{2}{*}{$0.0442^{*}$} & \multirow{2}{*}{$3.51(1.11-11.08)$} & \multirow{2}{*}{0.0442} \\
\hline & $>150$ & 183 & $12(7)$ & & & \\
\hline \multirow{2}{*}{ Average production } & Until 500kg & 194 & $4(2)$ & \multirow{2}{*}{$0.0722^{*}$} & \multirow{2}{*}{$3.15(0.99-9.94)$} & \multirow{2}{*}{0.0722} \\
\hline & $>500 \mathrm{~kg}$ & 193 & $12(6)$ & & & \\
\hline \multirow{2}{*}{ Age group } & Cows & 299 & $13(4)$ & \multirow{2}{*}{0.9329} & \multirow{2}{*}{-} & \multirow[b]{2}{*}{-} \\
\hline & Heifers & 88 & $3(3)$ & & & \\
\hline \multirow{3}{*}{ Breeding system } & Intensive & 50 & $2(4)$ & \multirow{3}{*}{0.3318} & \multirow{3}{*}{-} & \multirow{3}{*}{-} \\
\hline & Semi-Intensive & 293 & $14(5)$ & & & \\
\hline & Extensive & 44 & $0(0)$ & & & \\
\hline \multirow{2}{*}{ Breed } & Crossbreed & 279 & $13(5)$ & \multirow{2}{*}{0.5827} & \multirow{2}{*}{-} & \multirow{2}{*}{-} \\
\hline & Holstein & 108 & $3(3)$ & & & \\
\hline \multirow{2}{*}{ Quarentine } & No & 265 & $14(5)$ & \multirow{2}{*}{0.1621} & \multirow{2}{*}{-} & \multirow{2}{*}{-} \\
\hline & Yes & 122 & $2(2)$ & & & \\
\hline \multirow{2}{*}{ Milking type } & Manual & 16 & $4(25)$ & \multirow{2}{*}{$0.0003^{*}$} & \multirow{2}{*}{$9.97(2.80-35.49)$} & \multirow{2}{*}{0.0003} \\
\hline & Mechanic & 371 & $12(3)$ & & & \\
\hline \multirow{2}{*}{$\begin{array}{l}\text { Drying teats with } \\
\text { individual paper } \\
\text { towel }\end{array}$} & No & 84 & $4(5)$ & \multirow{2}{*}{0.9866} & \multirow[b]{2}{*}{-} & \multirow[b]{2}{*}{-} \\
\hline & Yes & 303 & $12(4)$ & & & \\
\hline \multirow{2}{*}{$\begin{array}{l}\text { Cleaning teats before } \\
\text { milking }\end{array}$} & No & 84 & $4(5)$ & & & \\
\hline & Yes & 303 & $12(4)$ & 0.9866 & - & - \\
\hline Cleaning teats after & No & 165 & $4(2)$ & & & \\
\hline milking & Yes & 222 & $12(5)$ & 0.2306 & - & - \\
\hline Milking animals & No & 22 & $4(18)$ & $00043^{*}$ & & \\
\hline with mastitis last & Yes & 365 & $12(3)$ & 0.0043 & $6.54(1.92-22.29)$ & 0.0043 \\
\hline Cleaning and & No & 145 & $7(5)$ & & & \\
\hline $\begin{array}{l}\text { desinfection of } \\
\text { stables and } \\
\text { surroundings }\end{array}$ & Yes & 242 & $9(4)$ & 0.7899 & - & - \\
\hline
\end{tabular}

${ }^{1}$ Associations evaluated by Pearson's Chi-square test. ${ }^{2}$ Associations evaluated by odds ratio.

* Significant associations $(\mathrm{P}<0.10)$.

reported in all herds in the current study. Although, not associated with mastitis, this species was already recovered from bulk tank milk from herds affected with mastitis of different etiologies and it is a predisposing agent to severe intramammary infection by other bacteria. Also, it can persist in milk over long periods, which is of great importance since it has been considered to have a zoonotic potential for immunocompromised individuals (STIPKOVITS et al., 2013).

Mycoplasma species can spread from one bovine body site to another via lymph or blood systems, and commonly cases of arthritis or respiratory disease can be associated with intramammary infection (FOX, 2012). This is the first report on the presence of $M$. bovis in dairy cows from Rio de Janeiro and $M$. arginini from
Minas Gerais, Rio de Janeiro and São Paulo, which demonstrated their circulation in these states.

There are some limitations in the current study, considering the impossibility to associate the presence of Mollicutes with intramammary infection, since in most farms there was not a continuous veterinary assistance and individual data of animals, such as clinical history of each dairy cow, data on somatic cell count and information about the use of antibiotics. However, it highlighted the importance of investigating the intramammary colonization of Mollicutes in dairy herds as a predisposing factor to mycoplasmosis or as a complicating factor to mastitis, due to possible synergistic interactions between mycoplasmas and other microorganisms, in addition to being possible pathogens in further bovine diseases. 
Table 3 - Description of positive samples for Mollicutes according to the origin and results in specific PCR.

\begin{tabular}{|c|c|c|c|}
\hline Sample designation & Herd designation & Location & Positivity in specific PCR \\
\hline 1 & A & Juiz de Fora - MG & M. arginini \\
\hline 2 & A & Juiz de Fora - MG & M. bovis + M. arginini \\
\hline 3 & $\mathrm{~A}$ & Juiz de Fora - MG & M. arginini \\
\hline 4 & $\mathrm{~B}$ & Rio Bonito - RJ & M. bovis \\
\hline 5 & $\mathrm{~B}$ & Rio Bonito - RJ & M. bovis \\
\hline 6 & $\mathrm{~B}$ & Rio Bonito - RJ & M. bovis + M. arginini \\
\hline 7 & $\mathrm{~B}$ & Rio Bonito - RJ & M. bovis + M. arginini \\
\hline 8 & $\mathrm{C}$ & Belmiro Braga - MG & $-^{*}$ \\
\hline 9 & $\mathrm{C}$ & Belmiro Braga - MG & M. arginini \\
\hline 10 & $\mathrm{C}$ & Belmiro Braga - MG & M. arginini \\
\hline 11 & $\mathrm{C}$ & Belmiro Braga - MG & M. arginini \\
\hline 12 & $\mathrm{C}$ & Belmiro Braga - MG & $-^{*}$ \\
\hline 13 & $\mathrm{C}$ & Belmiro Braga - MG & M. arginini \\
\hline 14 & $\mathrm{C}$ & Belmiro Braga - MG & M. arginini \\
\hline 15 & $\mathrm{D}$ & Areias - SP & $-{ }^{*}$ \\
\hline 16 & $\mathrm{D}$ & Areias - SP & M. arginini \\
\hline
\end{tabular}

*Positive samples for Mollicutes and negative for all specific PCR.

\section{CONCLUSION}

Mollicutes were present in dairy herds from Southeast Brazil, in states where its occurrence was unknown. Mycoplasma bovis and M. arginini were circulating in all states studied. This is the first report of M. bovis in Rio de Janeiro and M. arginini in the three states, being $M$. arginini present in all herds where Mollicutes were detected.

Herds with more than 150 animals, manual milking and not-milking animals with mastitis last were risk factors, suggesting that these conditions could favour intramammary colonization by Mollicutes in animals submitted to similar management conditions.

\section{ACKNOWLEDGMENTS}

To the "Coordenação de Aperfeiçoamento de Pessoal de Nível Superior" (CAPES), Brasil - Finance code 001, for the financial support to conduct this research. To those responsible for the herds for their availability to help, allowing the collection of biological material from the animals and for answering the epidemiological questionnaires.

\section{BIOETHICS AND BIOSSECURITY COMMITTEE APPROVAL}

This study was approved by the Ethics Committee on the Use of Animals (CEUA) of Universidade Federal Fluminense (UFF), under certificate number 987/2017.

\section{DECLARATION OF CONFLICT OF INTEREST}

The authors declare no conflict of interest. The founding sponsors had no role in the design of the study; in the collection, analyses, or interpretation of data; in the writing of the manuscript, and in the decision to publish the results.

\section{AUTHORS' CONTRIBUTIONS}

All authors contributed equally for the conception and writing of the manuscript. All authors critically revised the manuscript and approved of the final version.

\section{REFERENCES}

AL-MOMANI, W. et al. Risk factors associated with Mycoplasma agalactiae infection of small ruminants in northern Jordan. Preventive Veterinary Medicine, v.83, n.1, p.1-10, 2008. Available from: <https://pubmed.ncbi.nlm.nih.gov/17881071/>. Accessed: Oct. 21, 2020. doi: 10.1016/j.prevetmed.2007.08.003.

AYRES, M. et al. Bioestat 5.0: Aplicações estatísticas nas áreas das ciências biomédicas. Belém: ONG Mamiraua, 2007. 364 p.

BÜRKI, S. et al. Virulence, persistence and dissemination of Mycoplasma bovis. Veterinary Microbiology, v.179, n.1-2, p.15-22, 2015. Available from: <https://www.sciencedirect.com/ science/article/pii/S0378113515000796?via\%3Dihub>. Accessed: Jun. 15, 2020. doi: 10.1016/j.vetmic.2015.02.024.

CHALKER, V. J. et al. Mycoplasmas associated with canine infectious respiratory disease. Microbiology, v.150, n.10, p.3491- 
3497, 2004. Available from: <https://www.microbiologyresearch. org/content $/$ journal $/ \mathrm{micro} / 10.1099 / \mathrm{mic} .0 .26848-0 \#$ tab2 $>$. Acessed: Jun 05, 2020. doi: 10.1099/mic.0.26848-0.

CHÁVEZ-GONZÁLEZ, Y. R. et al. In vitro amplification of the 16s rRNA genes from Mycoplasma bovis and Mycoplasma agalactiae by PCR. Veterinary Microbiology, v.47, n. 1-2, p.183190, 1995. Available from: <https://www.sciencedirect.com/ science/article/pii/037811359500058I>. Accessed: Jun. 05, 2020. doi: 10.1016/0378-1135(95)00058-I.

DUSSURGET, O.; ROULLAND-DUSSOIX, D. Rapid, sensitive PCR- based detection of Mycoplasmas in stimulated samples of animal sera. Applied and Environmental Microbiology, v.60, n.3, p.953-959, 1994. Available from: <https://www.ncbi.nlm.nih. gov/pmc/articles/PMC201416/pdf/aem00020-199.pdf>. Accessed: Jun. 05, 2020. PMID: 8161186.

EMBRAPA. Anuário Leite 2019. Available from: <https:// www.infoteca.cnptia.embrapa.br/infoteca/handle/doc/1109959>. Accessed: Jun. 09, 2020.

FOX, L. K. Mycoplasma mastitis causes, transmission, and control. The Veterinary Clinincs: Food Animal Practice, v.28, n.2, p.225-237, 2012. Available from: $<$ https://pubmed.ncbi.nlm.nih.gov/16000109/>. Accessed: Jun. 15, 2020. doi: 10.1111/j.1439-0450.2005.00845.x.

FRANCHESCHINI, V. et al. Research for Mycoplasma spp. in milk samples from mastitic cows. Ars Veterinaria, v.22, n.2, p.130-134, 2008. Available from: <http://arsveterinaria.org.br/ index.php/ars/article/view/91/80>. Accessed: Jun. 05, 2020. doi: 10.15361/2175-0106.2006v22n2p130-134.

GIOIA, G. et al. Validation of a mycoplasma molecular diagnostic test and distribution of Mycoplasma species in bovine milk among New York dairy farms. Journal of Dairy Science, v.99, n.6, p.46684677, 2016. Available from: <https://www.journalofdairyscience. org/action/showPdf?pii=S0022-0302\%2816\%2930105-9>. Accessed: Jun. 05, 2020. doi: 10.3168/jds.2015-10724.

GONZÁLEZ, R. N.; WILSON, D.J. Mycoplasmal mastitis in dairy herds. Veterinary Clinics: Food Animal Practice, v.19, n.1, p.199-221, 2003. Available from: <https://www.sciencedirect. com/science/article/abs/pii/S0749072002000762?via\%3Dihub>. Accessed: Jun. 05, 2020. doi: 10.1016/s0749-0720(02)00076-2.

JOAQUIM, S. F. et al. Identification of subclinical mastitis caused by Mycoplasma spp. from screenings of bulk tanks. Arquivo Brasileiro de Medicina Veterinária e Zootecnia, v.70, n.6, p.1793-1797, 2018. Available from: <https://www.scielo.br/pdf/ abmvz/v70n6/0102-0935-abmvz-70-06-01793.pdf >. Accessed: Jun. 05, 2020. doi: 10.1590/1678-4162-9982.

JUNQUEIRA, N.B. Mycoplasma bovis como agente causal de mastite clínica bovina. 2017. 38p. Dissertation (Master in Veterinary Medicine) - Universidade Estadual Paulista.

KOBAYASHI, H. et al. In vitro amplification of the 16S rRNA genes from Mycoplasma bovirhinis, Mycoplasma alkalescens and Mycoplasma bovigenitalium by PCR. Journal of Veterinary Medical Science, v.6, n.12, p.1299-1303, 1998. Available from: $<$ https://www.jstage.jst.go.jp/article/jvms/60/12/60_12_1299/ pdf/-char/en>. Accessed: Jun. 05, 2020. doi: 10.1292/jvms.60.1299.

LANGE, M. J. et al. Typology of milking management: analysis of risk factors for subclinical mastitis. Pesquisa Veterinária
Brasileira, v.37, n.11, p.1205-1212, 2017. Available from: <https:// www.scielo.br/pdf/pvb/v37n11/1678-5150-pvb-37-11-01205.pdfs. Accessed: Jun. 15, 2020. doi: 10.1590/S0100-736X2017001100004.

LYSNYANSKY, I. et al. An overview of Mycoplasma bovis mastitis in Israel (2004-2014). The Veterinary Journal, v.207, p.180-183, 2015. Available from: <https://www.sciencedirect. com/science/article/abs/pii/S1090023315004682?via\%3Dihub>. Accessed: Jun. 10, 2020. doi: 10.1016/j.tvj1.2015.10.057.

MANZI, M. P. et al. Prevalence of Mycoplasma bovis in dairy herds. Pesquisa Veterinária Brasileira, v.38, n.4, p.665669, 2018. Available from: <https://www.scielo.br/pdf/pvb/ v38n4/1678-5150-pvb-38-04-665.pdf>. Accessed: Jun. 05, 2020. doi: 10.1590/1678-5150-pvb-5192.

MATOS, R. A. T. et al. Ocurrence and risk factors associated with Mycoplasma agalactiae infection in dairy goat herds of Paraíba State, Brazil. Pesquisa Veterinária Brasileira, v.39, n.2, p.93-98, 2019. Available from: <https://www.scielo.br/pdf/pvb/ v39n2/1678-5150-pvb-39-02-93.pdf >. Accessed: Oct. 21, 2020. doi: 10.1590/1678-5150-PVB-5538.

METTIFOGO, E. et al. Bovine mastitis by Mycoplasma bovis. Revista Brasileira de Medicina Veterinária, v.18, p.22-25, 1996.

MORTON, J. et al. Mycoplasma bovis in Australian dairy herds. Australian Veterinary Journal, v.92, n.9, p.322-323, 2014. Available from: < https://onlinelibrary.wiley.com/doi/full/10.1111/ avj.12243>. Accessed: Jun. 10, 2020. doi: 10.1111/avj.12243.

MURAI, K.; HIGUCHI, H. Prevalence and risk factors of Mycoplasma bovis infection in dairy in northern Japan. Research on Veterinary Science, v.123, p.29-31, 2019. Available from: <https://www.sciencedirect.com/science/article/abs/pii/ S0034528818314176>. Accessed: Oct. 21, 2020. doi: 10.1016/j. rvsc.2018.12.006.

NICHOLAS, R. A. J. et al. Mycoplasma mastitis in cattle: To cull or not to cull. The Veterinary Journal, v.216, p.142-147, 2016. Available from: <https://www.sciencedirect.com/science/article/ abs/pii/S1090023316301150?via\%3Dihub>. Accessed: Jun. 10, 2020. doi: $10.1016 /$ j.tvj1.2016.08.001.

PINHO, L. et al. Management practices associated with the bulk tank milk prevalence of Mycoplasma spp. in dairy herds in Northwestern Portugal. Preventive Veterinary Medicine, v.108, n.1, p.21-27, 2013. Available from: <https://www.sciencedirect. com/science/article/pii/S0167587712002115?via\%3Dihub>. Accessed: Jun. 10, 2020. doi: 10.1016/j.prevetmed.2012.07.001.

PRETTO, L. G. et al. Mastitis caused by Mycoplasma bovis in dairy cattle. Pesquisa Veterinária Brasileira, v.21, n.4, p.143145 , 2001. Available from: <https://www.scielo.br/pdf/pvb/ v21n4/7479.pdf > . Accessed: Jun. 05, 2020. doi: 10.1590/S0100736X2001000400003.

SALINA, A. et al. Microbiological and molecular detection of Mycoplasma bovis in milk samples from bovine clinical mastitis. Pesquisa Veterinária Brasileira, v.40, n.2, p.82-87, 2020. Available from: $<$ https://www.scielo.br/pdf/pvb/v40n2/1678-5150pvb-40-02-82.pdf $>$. Accessed: Jun. 10, 2020. doi: 10.1590/16785150-PVB-6259.

STIPKOVITS, L. et al. Role of Mycoplasma arginini in mastitis caused by Streptococcus dysgalactiae. Journal of 
Dairy Science, v.96, n.3, p.1661-1667, 2013. Available from: $<$ https://www.journalofdairyscience.org/action/showPdf?pii $=$ S0022-0302\%2813\%2900058-1>. Accessed: Jun. 15, 2020. doi: $10.3168 /$ jds.2012-5669.

TELLES, T. S. et al. Milk production systems in Southern Brazil. Anais da Academia Brasileira de Ciências, v.92, n.1, p.01-10, 2020. Available from: <https://www.scielo.br/pdf/aabc/ v92n1/0001-3765-aabc-92-01-e20180852.pdf>. Accessed: Jun. 15, 2020. doi: 10.1590/0001-3765202020180852.

THURSFIELD, M. Veterinary Epidemiology. Wiley-Blackwell, 2003. $483 \mathrm{p}$.

TIMONEN, A.A.E. et al. Within-herd prevalence of intramammary infection caused by Mycoplasma bovis and associations between cow udder health, milk yield, and composition. Journal of Dairy Science, v.100, n.8, p.6554-6561, 2017. Available from:
$<$ https://www.journalofdairyscience.org/action/showPdf?pii $=$ S0022-0302\%2817\%2930562-3>. Accessed: Jun. 05, 2020. doi: $10.3168 /$ jds.2016-12267.

VAN KUPPEVELD, F.J.M. et al. Genus- and species-specific identification of Mycoplasmas by $16 \mathrm{~S}$ rRNA amplification. Applied and Environmental Microbiology, v.58, n.8, p.26062615, 1992. Available from: <https://www.ncbi.nlm.nih.gov/pmc/ articles/PMC195828/pdf/aem00049-0274.pdf>. Accessed: Jul. 05, 2020. PMID: 1381174.

WAWEGAMA, N.K. et al. Evaluation of an IgG Enzyme-Linked Immunosorbent Assay as a serological assay for detection of Mycoplasma bovis infection in feedlot cattle. Journal of Clinical Microbiology, v.54, n.5, p.1270-1275, 2016. Available from: $<$ https://www.ncbi.nlm.nih.gov/pmc/articles/PMC4844740/ pdf/zjm1269.pdf>. Accessed: Jun. 10, 2020. doi: 10.1128/ JCM.02492-15. 